\title{
IMPACTS OF CLIMATE CHANGES ON HYDROLOGIC BALANCE: A CASE STUDY OF VOCHA PLAIN, KORINTHIA
}

\author{
Venetsanou P. ${ }^{1}$, Anagnostopoulou C. ${ }^{2}$ and Voudouris K. ${ }^{1}$ \\ ${ }^{1}$ Aristotle University of Thessaloniki, Department of Geology, Laboratory of Engineering Geology \\ and Hydrogeology, 54124, Thessaloniki, Greece,pvenetsn@geo.auth.gr,kvoudour@geo.auth.gr \\ ${ }^{2}$ Aristotle University of Thessaloniki, Department of Geology, Department of Meteorology and \\ Climatology, Thessaloniki, 54124, Greece, chanag@geo.auth.gr
}

\begin{abstract}
The aim of this study is to evaluate climate model hydrological parameters in comparison to recorded hydrological data and estimate the impacts of climate change on water balance. For this purpose, a combination of climate model precipitation and temperature data and Thornthwaite method was applied for the period 1988-2000 and the future periods 2028-2040, 2058-2070 and 2088-2100. The application of this combination was carried out in a coastal region in Southeastern part of Korinthiakos Gulf (southern Greece). The area is suitable for this target, because it is characterized by urbanization, intensive agriculture and tourism development, with increasing water demands. The evaluation of climate model parameters in comparison to observed data shows that the RegCM3 model is a reliable model. According to the future projections and the Thornthwaite method, the real evapotranspiration is estimated to increase, as a result precipitation decrease and temperature increase. Keywords: RegCM3, Thornthwaite method, Evapotranspiration.
\end{abstract}

\section{Пєрí $\eta \psi \eta$}

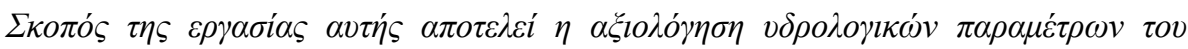

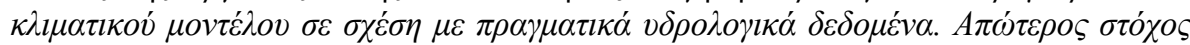

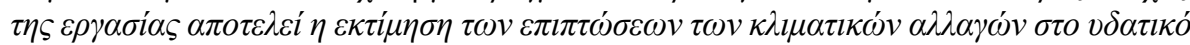

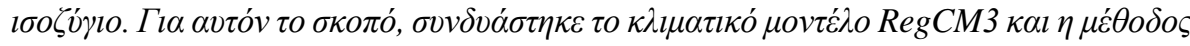

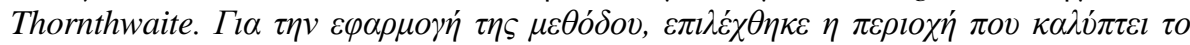

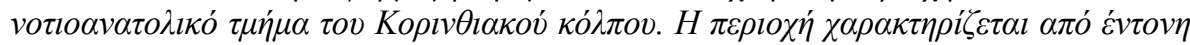

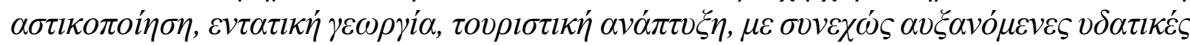

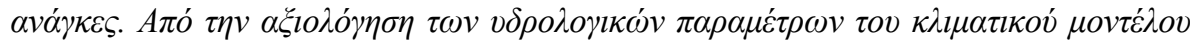

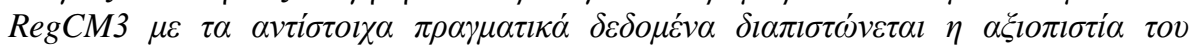

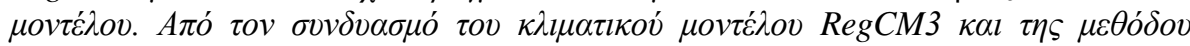

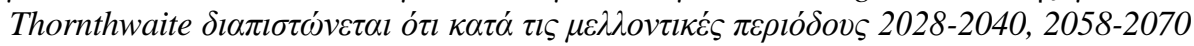

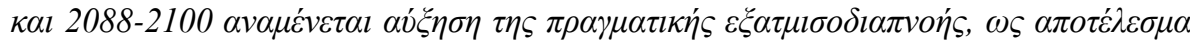

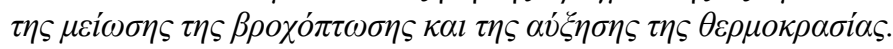

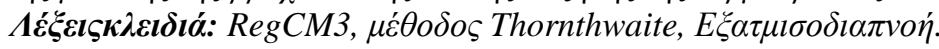

\section{Introduction}

During the last years, many regions are under pressure on water resources. Urbanization, rapid population growth, intensive agriculture, land use changes and industrial activities are the main 
pressures on water resources. Climate change is directly related to water resources; so is expected to exacerbate current stress on water resources (IPCC, 2008).

Climate change is unequivocal (IPCC, 2007; 2014), as is evident from increases in global air temperature and changes in rainfall regime. The main climate change impacts on water resources are shifts in precipitation and runoff, increases in temperature, evapotransporation and the frequency of flooding and droughts and sea level rises.

Hydrological cycle represents the water movement in, above and below Earth's surface. The hydrological cycle is driven by the solar energy. An intensification of the hydrological cycle is expected to happen due to higher levels of solar energy which trapped in atmosphere. As a result, climate change influence the hydrological cycle. Therefore, climate change affect on quantity, quality and accessibility of water supplies (EAA, 2007).

Previous investigations in temporal distribution in Greece exhibited a decreasing trend of rainfall (Voudouris et al., 2002). Furthermore, a seasonal shift of rainfall towards spring time in south Greece was also recently identified (Voudouris and Lambrakis, 1993). This shift resulted in an increase in actual evapotranspiration, due to increased air temperature, and diminishing of aquifer recharge. Venetsanou et al. (2014) estimated the impacts of climate changes on groundwater in a coastal area of Peraia-Epanomy (northern Greece) and found a reduction of rainfall by $4 \%$ during the future period 2021-2050.

The General Circulation Models (GCMs) and Regional Climate Models (RCMs) remain the most important and appropriate tools to assess the future global climate change and evaluate the development of climate scenarios. Downscaling methods have been developed because of the need for regional projections and hydrological studies (Fowler et al., 2007). The downscaling methods are divided into categories: the dynamical method and the statistical methods. The dynamical process use physically based regional climate models (RCMs). On the other hand, the statistical processes provide statistical relationships to define independent (predictor) and dependent (predictants) variables (IPCC, 2007).

The objectives of this study are initially the evaluation of climate model parameters (rainfall and temperature) versus observed data to estimate the water balance in a coastal catchment of south Greece. The ultimate objective is to achieve the impacts of climate change on water balance in the selected region for the future period.

\section{Study Area}

The study region, called as Vocha plain, is located in southern Greece, in northeastern Peloponnesus Prefecture and is extended in the costal part of northeastern Korinthiakos Gulf (Figure 1). It consists of Municipality of Velou-Vocha and the Municipalities of Korinthos and Kiato and comprises 65 $\mathrm{Km}^{2}$. It covers the discharge section of the catchments: Asopos, Zapantis, Rachianis, and Xerias. The altitude varies from 0 to $40 \mathrm{~m}$ above sea and consequently, the research area is described as flat.

The total population is about 87,000 residents, according to the National Statistical Service of Greece (2011). In last decades, rapid growth population has been observed. During the summer months, the population increases dramatically due to the tourism. The area is characterized by urbanization, intensive agriculture and tourism development, with increasing water demands. The cultivated land is about $45 \mathrm{Km}^{2}$ and the main crops are olives, citrus fruits, apricots and vineyards. According to Köppen climate classification the climate of the research area is characterized as Mediterranean (Csa).According to the climate data of the official meteorological station 'Velo' in Velo Korinthia of the Hellenic Meteorological Service for the period 1988-2000, the mean annual precipitation is $479 \mathrm{~mm}$, the mean annual temperature is $17.5^{\circ} \mathrm{C}$ and the relative humidity varies from $52 \%$ to $76 \%$. The surface runoff is temporal during the wintertime, with a considerable drainage network, which flows in Korinthiakos Gulf. The drainage network is represented, mainly, by the river Asopos, Zapantis, Xerias and Rachianis. 


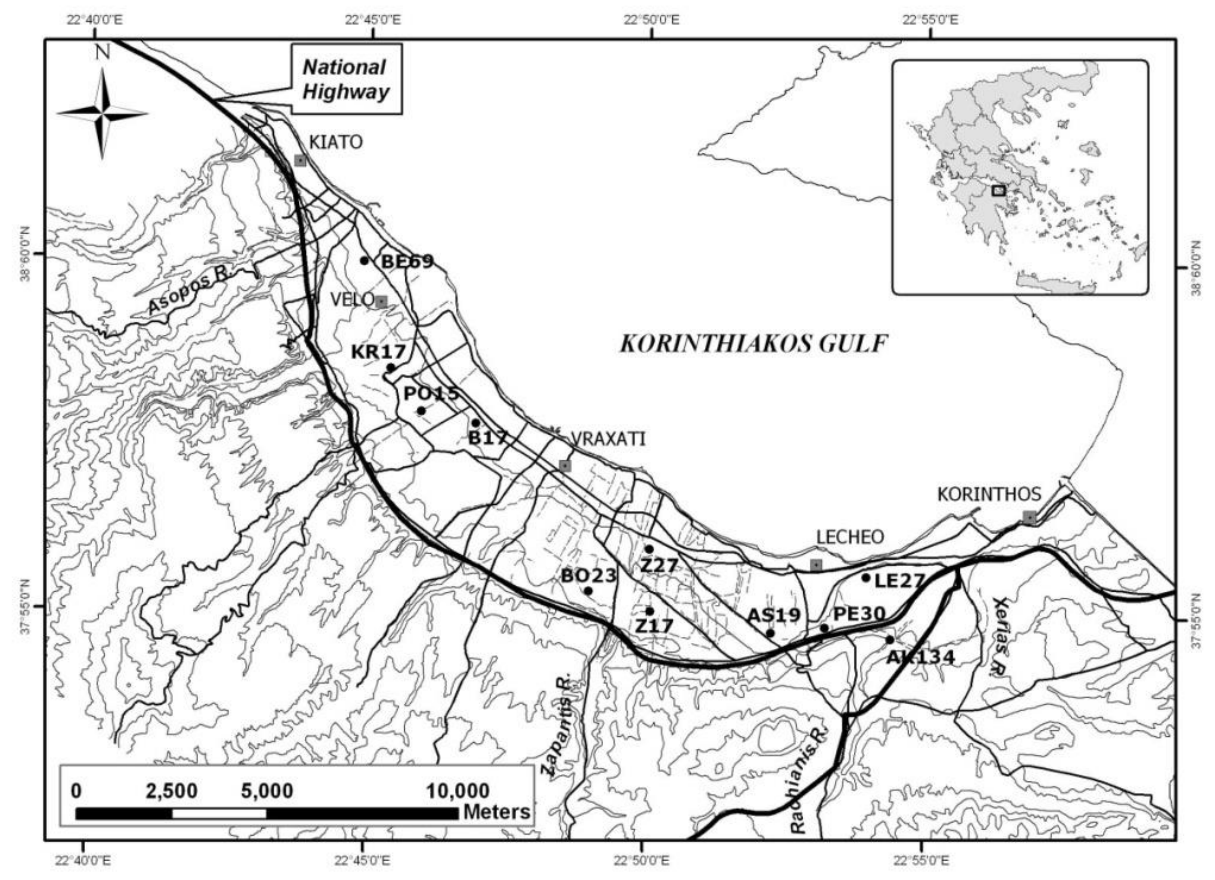

Figure 1 - The study area and the location of the meteorological station Velo (Voudouris, 2006).

From a geological point of view, the research area is covered from Neogene and Quaternary sedimentary formations. The Neogene sedimentary formations consist of sandstone, gravel, conglomerates, marls and lagoon sediments. The Quaternary sediments are sands, pebbles, breccias and fine clay to silty sand deposits (alluvial deposits), scree-talus cones and other marine deposits. The deposits are characterized by heterogeneity and anisotropy. The thickness of the deposits ranges between $30 \mathrm{~m}$ and $70 \mathrm{~m}$.

The main aquifer system is developed within alluvial deposits. The alluvial aquifer is phreatic. The aquifer system is recharged mainly by direct infiltration of precipitation, infiltration through river, artificial recharge due to flood, irrigation returns and lateral groundwater fluxes (Voudouris, 2006).

The fluctuation of the water table elevation varies from $0.5 \mathrm{~m}$ to $3 \mathrm{~m}$ below ground surface in the coastal area and $15 \mathrm{~m}$ to $20 \mathrm{~m}$ below ground surface in the southern part of the research study. The main groundwater's flow direction is S-N (toward the Korinthiakos Gulf). The safe yield of the aquifer system varies from $32 \times 10^{6}$ to $37 \times 10^{6} \mathrm{~m}^{3} / \mathrm{yr}$ (Voudouris, 2006). The average hydraulic conductivity is $\mathrm{k}=1.4 \times 10^{-}$ ${ }^{4} \mathrm{~m} / \mathrm{s}$, as determined from the pumping test analyses (Panagopoulos et al., 2002).

\section{Materials and Methods}

\subsection{Climate Data}

Daily temperature and precipitation dataset from the regional climate model RegCM simulations have been taken into consideration in this paper. The RegCM simulations were carried out in the framework of the CCSeaWavs NSRF-EU project (http://thalis-ccseawavs.web.auth.gr/en/). The RegCM3 model was initially created by Giorgi et al. (1993a, b) and was later modified and improved by Giorgi and Means (1999) and Pal et al. (2007) (http://www.ictp.trieste.it/ pubregcm/RegCM3/).

The RegCM3 climate model has been dynamically downscaled to a high spatial resolution of $10 \mathrm{~km}$ $\mathrm{x} 10 \mathrm{~km}$, it is driven by ECHAM5 Global Climate Model (GCM) and it follows the A1B emission scenario for future climate projections. The A1B is based on the assumption of a world of rapid economic growth and introduction of new technologies, which are used with a balance across all 
sources (IPCC, 2007). The data correspond to the control period of 1988-2000, and the future projections for the period of 2028-2040 (first future period), 2058-2070 (second future period) and 2088-2100 (third future period).

Forty two grid points (Figure 2) were selected to analyze the temperature and precipitation in the study area. The RegCM data was evaluated by using the precipitation and temperature data obtained from the official WMO meteorological station of the Hellenic Meteorological Service at Velo (Velo Korinthia station). Furthermore, the observed dataset was collected by the research: Groundwater balance and safe yield of the coastal aquifer system in north-eastern Korinthia, Greece (Voudouris, 2006).

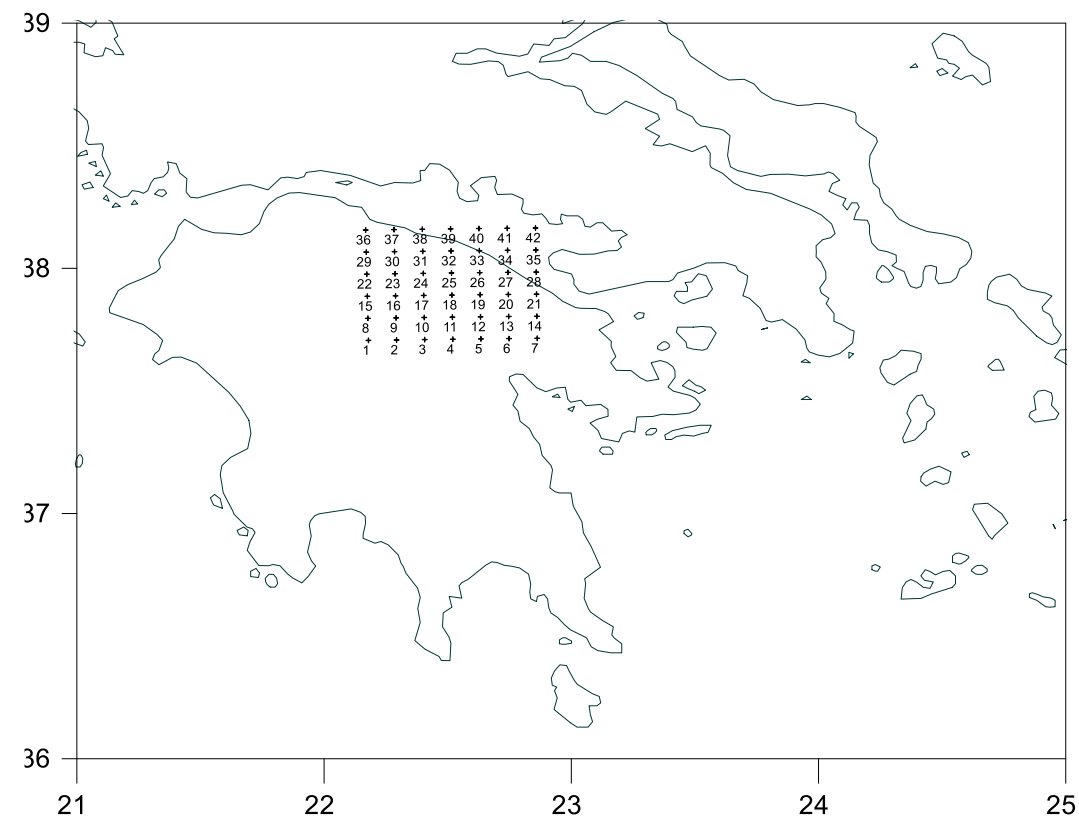

Figure 2 - Grid points in research area.

\subsection{Methodology}

The water balance equation in a basin is given by the following equation:

$\mathrm{P}=\mathrm{E}+\mathrm{R}+\mathrm{I}+\Delta \mathrm{S} \pm \mathrm{dq}$

Where $\mathrm{P}=$ Precipitation, $\mathrm{E}=$ Real Evapotranspiration, $\mathrm{R}=$ Runoff, $\mathrm{I}=$ Infiltration, $\Delta \mathrm{S}=$ changes in soil storage, $\mathrm{dq}=$ the result of human intervention.

Considering the factors $\Delta \mathrm{S}$ and dq as negligible, the above equation becomes: $\mathrm{P}=\mathrm{E}+\mathrm{R}+\mathrm{I}$

The Thornthwaite method is worldwide applied in order to estimate the potential evapotransporation which is mainly dependent on temperature (Thornthwaite, 1948). The potential evapotranspiration (Ep) is calculated by:

$\operatorname{Ep}(\mathrm{mm})=16(10 \mathrm{~T} / \mathrm{I})^{\mathrm{a}}$

Where $\mathrm{T}=$ the monthly temperature $\left({ }^{\circ} \mathrm{C}\right)$ and $\mathrm{I}=$ the annual heat index:

$\mathrm{I}=\sum_{1}^{12} i_{j}$

Where $\mathrm{i}_{\mathrm{j}}=$ the monthly heat index of the month $\mathrm{j}$;

$\mathrm{i}_{\mathrm{j}}=(\mathrm{T} / 5)^{1.514}$ 
The coefficient a is given by the formula:

$\mathrm{a}=0.49239+\left(1792 \times 10^{-5}\right) \mathrm{I}-\left(771 \times 10^{-7}\right) \mathrm{I}^{2}+\left(675 \times 10^{-9}\right) \mathrm{I}^{3}$

The corrected potential evapotransporation is calculated by the formula:

$\mathrm{Ep}=\mathrm{Ep} \cdot \mathrm{N}$

Where: $\mathrm{N}$, is a factor which depends on latitude.

The Thornthwaite-Matter method is used in order to estimate the real evapotransporation (Thornthwaite and Mather, 1955). The real evapotranspiration (Er) is calculated as follows:

1) When $\mathrm{Ep}^{\prime} \leq \mathrm{P}$ then $\mathrm{Er}=\mathrm{Ep}^{\prime}$

In this case water surplus is given by: $\mathrm{Q}=\mathrm{P}-\mathrm{Er}$ and $\mathrm{W} s \mathrm{i}=\mathrm{W} \max$

Where: $\mathrm{P}=$ rainfall, $\mathrm{Q}=$ total water surplus (infiltration and runoff), $\mathrm{Ws}_{\mathrm{i}}=$ the water amount in the soil for i-month, Wmax=the maximum water storage in the soil depending on the soil features.

2) When $\mathrm{Ep}^{\prime} \mathrm{Ep}^{\prime} \geq \mathrm{P}$ then $\geq \mathrm{P}$ then $\mathrm{Er}=\mathrm{P}+|\Delta \mathrm{Ws}|$

Where: $\Delta \mathrm{Ws}=\mathrm{Ws}_{\mathrm{i}}-\mathrm{Ws}_{\mathrm{i}-1}$

The water amount in the soil $\left(\mathrm{Ws}_{\mathrm{i}}\right)$ for i-month and is calculated by the formula:

$\mathrm{Ws}_{\mathrm{i}}=\mathrm{Wmax} \mathrm{e}^{-(\mid \mathrm{APWL} / \mathrm{Wmax})}$

Where: Wmax were defined earlier and $\mathrm{APWL}=$ accumulated potential water loss (P-Ep').

In this case water surplus $=0$. The water surplus exists if the water storage in soil has the maximum value. A software programme, which developed by Voudouris and Danopoulos (1993), was applied in order to calculate the water balance.

\section{Results and Discussion}

\subsection{Climate Model}

The precipitation data for each of 42 grid points were evaluated in comparison to the observed station data (Velo station) (Figure 2).The processing of precipitation data shows that 8 grid points, which are the closest grid points to Velo station (reference station) are representative for this study.

The diagram depicts the observed and predicted average monthly precipitation data for the eight grid points (Figure 3). From the diagram, it can be derived that selected grid points set out a uniform distribution of rainfall in comparison to the reference station. The maximum precipitation is observed in November, while the minimum precipitation in June. RegCM3 model presents a slight overestimation, of the winter precipitation, while underestimates the summer precipitation. The mean annual precipitation for the Velo Station is $478.8 \mathrm{~mm}$, while the mean annual precipitation for the eight grid points is very close $(501.8 \mathrm{~mm})$.

The mean annual temperature is $17.5^{\circ} \mathrm{C}$ for the reference station, while the corresponding mean temperature of the eight grid points is $16.03^{\circ} \mathrm{C}$. For the study region, RegCM3 shows colder summer than the observed station. On the other hand, in many studies are proved that temperature is going to increase during the future periods (Tolika et al., 2012). 


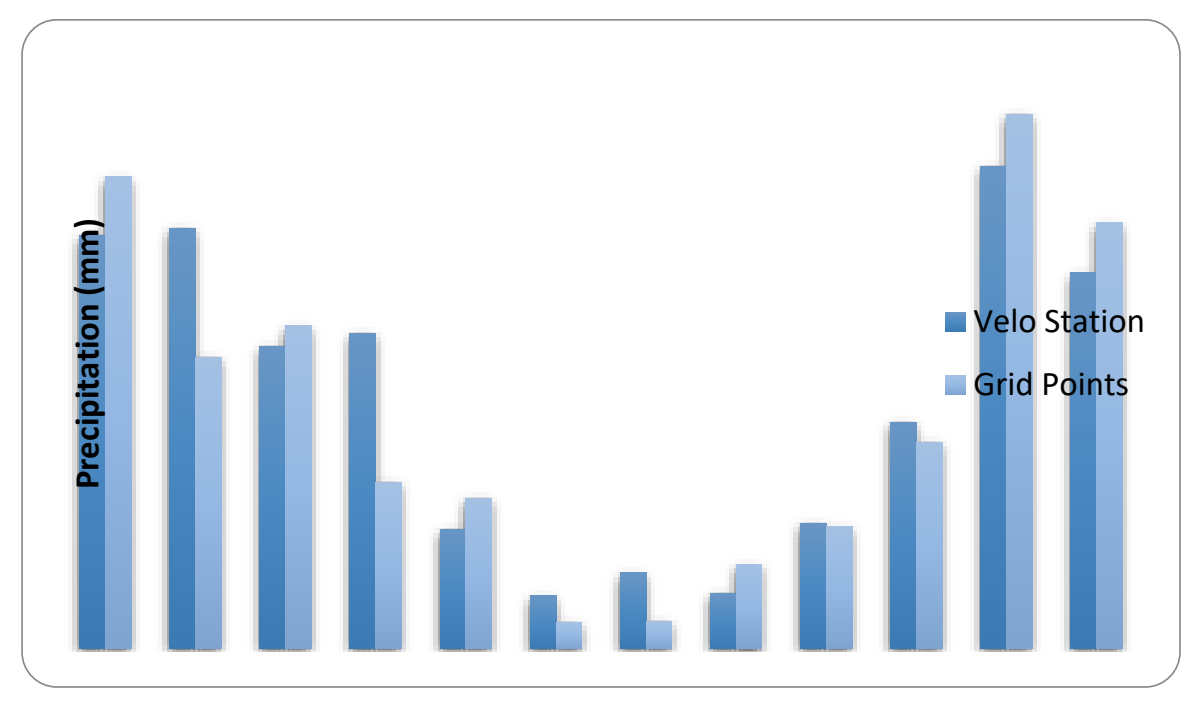

Figure 3 - Rainfall distribution between Velo station and grid points.

\subsection{Water Balance}

According to Thornthwaite method, the mean real evapotranspiration for the reference station during the period 1988-2000, is $346.9 \mathrm{~mm}$ and represents about $73 \%$ of mean annual precipitation (478.8 $\mathrm{mm}$ ). It is mentioned that, the maximum water storage in the soil is $110 \mathrm{~mm}$ (Touazi et al., 2004). The infiltration and surface runoff $(\mathrm{Q})$ are $131.9 \mathrm{~mm}$ (27\% of annual average precipitation). Table 1 presents the Thornthwaite method, where $\mathrm{T}=$ temperature, $\mathrm{i}=$ heat index, $\mathrm{E}_{\mathrm{p}}=$ potential evapotranspiration, $\mathrm{N}=$ factor depending on latitude, $\mathrm{E}_{\mathrm{p}}{ }^{\prime}=$ corrected potential evapotranspiration, $\mathrm{P}=$ precipitation, $\mathrm{APWL}=$ accumulated potential water loss, $\mathrm{Wmax}=$ maximum water storage in the soil, $\Delta \mathrm{Ws}=\mathrm{Ws}_{\mathrm{i}}-\mathrm{Ws}_{\mathrm{i}-1}, \mathrm{E}_{\mathrm{r}}=$ real evapotranspiration.

The mean real evapotransporation was estimated for the mean grid of the eight grid points during the period 1988-2000, based on Thornthwaite method. It is $381.6 \mathrm{~mm}$ representing about $76 \%$ of mean annual precipitation $(501.8 \mathrm{~mm})$. Therefore, the similarity in annual evapotranspiration between the reference station and the model is obvious. The infiltration and runoff $(\mathrm{Q})$ are $133.9 \mathrm{~mm}$.

The difference between real evapotransporation (Ep) and precipitation $(\mathrm{P})$ called as water deficit (Sreedevi, 2002). The water budget in Velo station shows that water deficit is observed during the dry period (April-September), while water surplus and natural recharge is recorded during the wet period (January-March). During the period October-December is the replenishment period of water storage in the soil. It is pointed out that the maximum water soil reaches $110 \mathrm{~mm}$ in December (end of the year).

According to the RegCM3 model, the water deficit is observed during the period April-September, while the water surplus is recorded during the period January-March. The replenishment period of water storage in the soil is observed during the period October-December. The maximum water soil is $96.2 \mathrm{~mm}$ in December (Table 1).

\subsection{Future projections}

According to the RegCM model the precipitation is estimated to reduce around $10 \%$ for each of the future periods 2028-2040, 2058-2070 and 2088-2100. The mean future precipitation is gradually reduced and it is estimated to be equal to $437.1 \mathrm{~mm}$ for the third future period (2088-2100). For the same future period, the mean annual temperature will be $19.03^{\circ} \mathrm{C}$. It is mentioned that, the temperature is estimated to increase significantly during the summer months (not shown). 
The Thornthwaite method was applied on RegCM simulations in order to assess the water balance for the future periods 2028-2040, 2058-2070 and 2088-2100. It is pointed out that the maximum water storage in the soil, keeping stable $(110 \mathrm{~mm})$ for the whole future periods. The real evapotransporation is estimated to increase by 5\%, 7.5\% and 10\% during 2028-2040, 2058-2070 and 2088-2100, respectively. The real evapotransporation is estimated equal to $376.5 \mathrm{~mm}$ and it represents about $86 \%$ of mean annual precipitation $(437.1 \mathrm{~mm})$ for the third future period (20882100). The annual runoff and infiltration are estimated to be $103.6 \mathrm{~mm}$ (Table 2).

According to the RegCM3 model, the water deficit is observed during the period April-October, while the water surplus and natural recharge is recorded during the period (January-March). The replenishment period of water storage in the soil is observed during the period November-December (Figure 4).

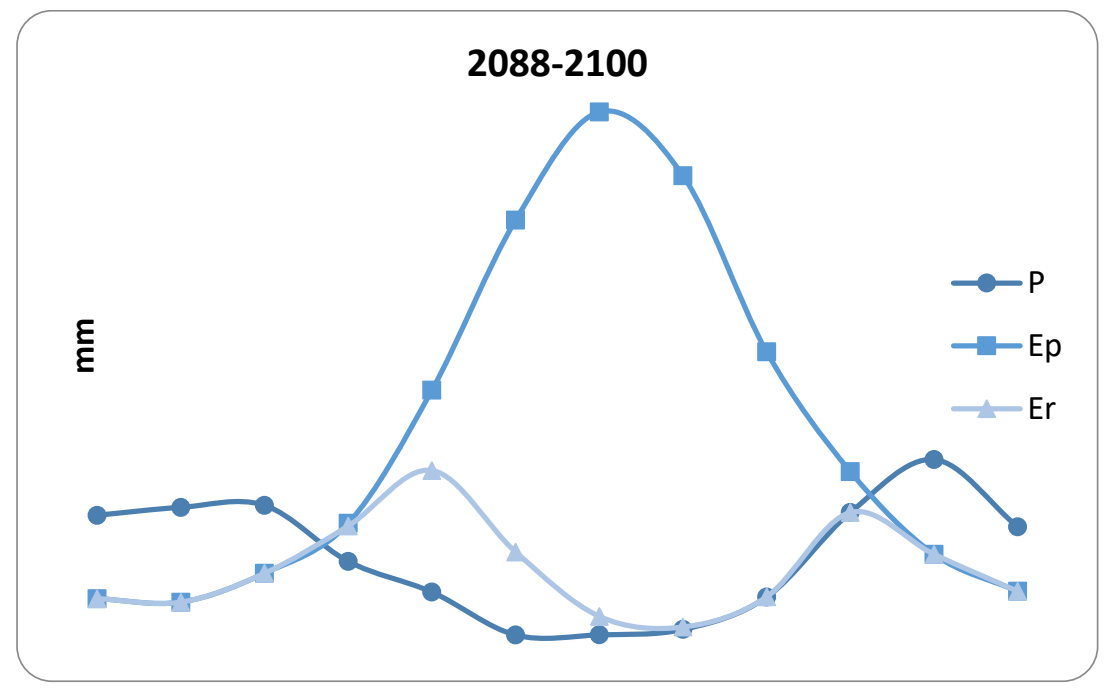

Figure 4 - Mean hydrologic balance $(\mathrm{mm})$ for the future period 2088-2100 ( $\mathrm{P}=$ rainfall, $\mathrm{Ep}=$ Corrected potential evapotranspiration, $\mathrm{Er}=$ Real evapotranspiration).

Table 1 - Water balance for the period 1988-2000.

\begin{tabular}{|c|c|c|c|c|c|c|c|c|c|c|c|c|c|}
\hline \multicolumn{14}{|c|}{ Water balance-Velo Station } \\
\hline \multicolumn{5}{|c|}{$\mathrm{Wmax}=110 \mathrm{~mm}$} & \multicolumn{4}{|c|}{$a=1,863$} & \multicolumn{5}{|c|}{$\begin{array}{c}\text { Coefficient of real Evapotranspira } \\
\text { tion }=73 \%\end{array}$} \\
\hline & I & $\Phi$ & $\mathbf{M}$ & $\mathbf{A}$ & $\mathbf{M}$ & I & I & $\mathbf{A}$ & $\Sigma$ & $\mathbf{O}$ & $\mathbf{N}$ & $\Delta$ & Mean \\
\hline $\mathbf{T}^{0} \mathrm{C}$ & 8,80 & 9,10 & 11,2 & 15,00 & 20,30 & 25,30 & 27,90 & 27,20 & 23,20 & 18,30 & 13,10 & 10,00 & $\mathbf{1 7 , 5}$ \\
\hline $\mathrm{i}$ & 2,35 & 2,48 & 3,39 & 5,28 & 8,34 & 11,64 & 13,50 & 12,99 & 10,21 & 7,13 & 4,30 & 2,86 & 84,47 \\
\hline $\mathbf{E}_{\mathbf{p}}{ }^{\prime}$ & 17,27 & 718,38 & 27,1 & 46,63 & 81,93 & 123,48 & 148,16 & 141,31 & 105,07 & 767,54 & 36,23 & 21,91 & \\
\hline $\mathbf{N}$ & 0,83 & 0,83 & 1,03 & 1,11 & 1,25 & 1,26 & 1,27 & 1,19 & 1,04 & 0,96 & 0,82 & 0,8 & \\
\hline $\mathbf{E}_{\mathbf{p}}$ & 14,3 & 15,3 & 27,9 & 51,8 & 102,4 & 155,6 & 188,2 & 168,2 & 109,3 & 64,8 & 29,7 & 17,5 & 944,88 \\
\hline $\mathbf{P}(\mathrm{mm})$ & 79,90 & 049,30 & 54,7 & 28,20 & 25,40 & 4,45 & 4,60 & 14,20 & 20,60 & 34,90 & 90,40 & 72,10 & 478,8 \\
\hline $\mathbf{P}-\mathbf{E P} \mathbf{P}^{\prime}$ & 0,0 & 0,0 & 0,0 & 23,6 & 77,0 & 151,1 & 183,6 & 154,0 & 88,7 & 29,9 & 0,0 & 0,0 & \\
\hline APWL & 0,0 & 0,0 & 0,0 & $-23,6$ & -100 & $-251,7$ & $-435,3$ & $-589,2$ & $-677,9$ & $-707,8$ & 0,0 & 0,0 & \\
\hline Ws & 110,0 & 0110,0 & 110 , & 88,8 & 44,1 & 11,2 & 2,1 & 0,5 & 0,2 & 0,2 & 60,9 & 110,0 & \\
\hline$\Delta W s$ & 0,0 & 0,0 & 0,0 & $-21,2$ & $-44,7$ & $-32,9$ & $-9,1$ & $-1,6$ & $-0,3$ & $-0,1$ & 60,7 & 49,1 & \\
\hline Er & 14,3 & 15,3 & 27,9 & 49,4 & 70,1 & 37,4 & 13,7 & 15,8 & 20,9 & 35,0 & 29,7 & 17,5 & 346,9 \\
\hline $\mathbf{Q}$ & 65,6 & 34,0 & 26,8 & 0,0 & 0,0 & 0,0 & 0,0 & 0,0 & 0,0 & 0,0 & 0,0 & 5,4 & 131,9 \\
\hline \multicolumn{14}{|c|}{ Water balance-Climate model } \\
\hline
\end{tabular}




\begin{tabular}{|c|c|c|c|c|c|c|c|c|c|c|c|c|c|}
\hline \multicolumn{5}{|c|}{$W \max =110 \mathrm{~mm}$} & \multicolumn{4}{|c|}{$a=1,669$} & \multicolumn{5}{|c|}{$\begin{array}{c}\text { Coefficient of real Evapotranspira } \\
\text { tion }=76 \%\end{array}$} \\
\hline & I & $\Phi$ & $\mathbf{M}$ & $\mathbf{A}$ & $\mathbf{M}$ & II & II & $\mathbf{A}$ & $\Sigma$ & $\mathbf{0}$ & $\mathbf{N}$ & $\Delta$ & Mean \\
\hline $\mathbf{T}^{0} \mathrm{C}$ & 8,44 & 8,78 & 10,2 & 13,64 & 18,27 & 23,52 & 25,58 & 25,19 & 20,82 & 15,98 & 12,59 & 8,99 & 16,03 \\
\hline i & 2,21 & 2,34 & 2,94 & 4,57 & 7,11 & 10,43 & 111,84 & 11,56 & 8,67 & 5,81 & 4,05 & 2,43 & 73 \\
\hline $\mathbf{E}_{p^{\prime}}$ & 19,92 & 421,30 & 27,3 & 44,47 & 72,40 & 110,34 & 4126,91 & 123,70 & 89,99 & 57,90 & 38,86 & 22,16 & \\
\hline $\mathbf{N}$ & 0,83 & 0,83 & 1,03 & 1,11 & 1,25 & 1,26 & 1,27 & 1,19 & 1,04 & 0,96 & 0,82 & 0,8 & \\
\hline $\mathbf{E}_{\mathrm{p}}$ & 16,5 & 17,7 & 28,1 & 49,4 & 90,5 & 139,0 & 161,2 & 147,2 & 93. & 55,6 & 31,9 & 17,7 & 848,4 \\
\hline $\mathbf{P}(\mathbf{m m})$ & 69,95 & 571,14 & 51,2 & 53,40 & 20,18 & 8,92 & 12,86 & 9,41 & 21,21 & 38,28 & 81,63 & 63,63 & 501 \\
\hline P-EP' & 0,0 & 0,0 & 0,0 & 0,0 & 70,3 & 130,1 & 148,3 & 137,8 & 72,4 & 17,3 & 0,0 & 0,0 & \\
\hline APWL & 0,0 & 0,0 & 0,0 & 0,0 & $-70,3$ & $-200,4$ & $-348,7$ & $-486,5$ & $-558,9$ & $-576,2$ & 0,0 & 0,0 & \\
\hline Ws & 110, & 1110,0 & 110 & 110,0 & 58,0 & 17,8 & 4,6 & 1,3 & 0,7 & 0,6 & 50,4 & 96,2 & \\
\hline$\Delta \mathbf{W s}$ & 0,0 & 0,0 & 0,0 & 0,0 & $-52,0$ & $-40,3$ & $-13,2$ & $-3,3$ & $-0,6$ & $-0,1$ & 49,8 & 45,9 & \\
\hline $\mathbf{E r}$ & 16,5 & 17,7 & 28,1 & 49,4 & 72,1 & 49,2 & 26,0 & 12,7 & 21,8 & 38,4 & 31,9 & 17,7 & 381 . \\
\hline $\mathbf{Q}$ & 53,4 & 53,5 & 23,0 & 4,0 & 0,0 & 0,0 & 0,0 & 0,0 & 0,0 & 0,0 & 0,0 & 0,0 & 133 \\
\hline
\end{tabular}

Table 2 - Water balance for the period 2088-2100.

\begin{tabular}{|c|c|c|c|c|c|c|c|c|c|c|c|c|c|}
\hline \multicolumn{14}{|c|}{ Water balance model } \\
\hline \multicolumn{5}{|c|}{ Wmax $=110 \mathrm{~mm}$} & \multicolumn{4}{|c|}{$a=2,131$} & \multicolumn{5}{|c|}{$\begin{array}{c}\text { Coefficient of real Evapotranspira } \\
\text { tion }=\mathbf{8 6 \%}\end{array}$} \\
\hline & II & $\Phi$ & $\mathbf{M}$ & $\mathbf{A}$ & $\mathbf{M}$ & I & I & $\mathbf{A}$ & $\Sigma$ & $\mathbf{O}$ & $\mathbf{N}$ & $\Delta$ & Mean \\
\hline $\mathbf{T}^{0} \mathrm{C}$ & 11,42 & 10,99 & 12,8 & 15,89 & 21,35 & 27,07 & 30,02 & 29,15 & 24,87 & 20,13 & 15,91 & 12,49 & 19,38 \\
\hline 1 & 3,49 & 3,30 & 4,13 & 5,76 & 9,00 & 12,90 & 15,08 & 14,43 & 11,34 & 8,24 & 5,77 & 4,00 & 97,44 \\
\hline $\mathbf{E}_{\mathbf{p}}^{\prime}$ & 22,43 & 20,69 & 28,5 & 45,34 & 85,09 & 141,21 & 175,96 & 165,27 & $7 \mid 117,79$ & 75,12 & 45,49 & 27,17 & \\
\hline $\mathbf{N}$ & 0,83 & 0,83 & 1,03 & 1,11 & 1,25 & 1,26 & 1,27 & 1,19 & 1,04 & 0,96 & 0,82 & 0,8 & \\
\hline $\mathbf{E}_{\mathrm{p}}$ & 18,6 & 17,2 & 29,3 & 50,3 & 106,4 & 177,9 & 223,5 & 196,7 & 122,5 & 72,1 & 37,3 & 21,7 & 1073,51 \\
\hline $\mathbf{P ( \mathbf { m m } )}$ & 53,74 & 57,04 & 57,9 & 34,31 & 21,43 & 3,35 & 3,42 & 5,70 & 19,30 & 54,89 & 77,16 & 48,84 & 437,1 \\
\hline P-Ep' & 0,0 & 0,0 & 0,0 & 16,0 & 84,9 & 174,6 & 220,1 & 191,0 & 103,2 & 17,2 & 0,0 & 0,0 & \\
\hline APWL & 0,0 & 0,0 & 0,0 & $-16,0$ & -101 & $-275,5$ & $-495,6$ & $-686,5$ & $-789,7$ & $-807,0$ & 0,0 & 0,0 & \\
\hline Ws & 110,0 & 110,0 & 110 & 95,1 & 43,9 & 9,0 & 1,2 & 0,2 & 0,1 & 0,1 & 39,9 & 67,0 & \\
\hline$\Delta \mathrm{Ws}$ & 0,0 & 0,0 & 0,0 & $-14,9$ & $-51,2$ & $-35,0$ & $-7,8$ & $-1,0$ & $-0,1$ & 0,0 & 39,9 & 27,1 & \\
\hline $\mathbf{E r}$ & 18,6 & 17,2 & 29,3 & 49,2 & 72,6 & 38,3 & 11,2 & 6,7 & 19,4 & 54,9 & 37,3 & 21,7 & 376,5 \\
\hline $\mathbf{Q}$ & 35,1 & 39,9 & 28,6 & 0,0 & 0,0 & 0,0 & 0,0 & 0,0 & 0,0 & 0,0 & 0,0 & 0,0 & 103,6 \\
\hline
\end{tabular}

\section{Conclusions}

The objective of this study was the assessment of climate change impacts on water balance for a coastal region in Southeastern part of Korinthiakos Gulf (southern Greece). For this purpose, Thornthwaite method was applied on precipitation and temperature data of a regional climate model RegCM3, following the A1B climate scenarios.

The evaluation of climate model parameters shows that the RegCM3 model presents reliable simulations for the study region. The model infiltration and runoff $(\mathrm{Q})$ was very close to the observed one, with a bias equal to $2 \mathrm{~mm} / \mathrm{yr}$.

According to the Thornthwaite method results for the future periods, the real evapotranspiration is estimated to increase as a result of the precipitation decrease and temperature increase. Especially, at the end of $21^{\text {th }}$ century, the temperature changes caused by scenarios $\Delta \mathrm{T}=3.35^{\circ} \mathrm{C}$ combined with precipitation decreases showed a strong decrease in runoff especially at the beginning and the end of the winter. Increased temperature increase spring and summer actual evapotranspiration, this 
could reinforce the effect of the precipitation decrease during warm period (May to October) resulting to runoff that presents the smallest duration from January to March.

The area of eastern part of Korinthiakos Gulf is under pressure as regards water recourses. Climate change challenges further pressure. Changes in precipitation, temperature and evapotranspiration influence the quantity, quality and accessibility of water resources in the research area. Future investigations of the sustainable management of water resources in Korinthia would benefit by climatic, hydrological, land use monitoring, groundwater table measurements and computer modeling to simulate the hydrological cycle.

\section{References}

European Environment Agency (EAA), 2007. Climate change and water adaption issues, EEA Technical report (2), European Environment Agency, Copenhagen.

Fowler, H.J., Blenkisop, S. and Tebaldi, C., 2007. Linking climate change modeling to impacts studies: recent advances in downscaling modeling, International Journal Climatology, 27 $1547-1578$.

Giorgi, F., Marinucci, M.R. and Bates, G.T., 1993a. Development of a second generation regional climate model (RegCM2). Part I: Boundary layer and radiative transfer process, Monthly Weather Review, 121, 2794-2813.

Giorgi, F., Marinucci, M.R., Bates, G.T. and DeCanio, G., 1993b. Development of a second generation regional climate model (RegCM2). Part II: Convective processes and assimilation of lateral boundary conditions, Monthly Weather Review, 121, 2814-2832.

Giorgi, F. and Mearns, L.O., 1999. Introduction to special section: regional climate modeling revisited, Journal of Geophysical Research, 104, 6335-6352.

IPCC, 2007. Synthesis Report, An Assessment of the Intergovernmental Panel on Climate Change, www.ipcc.ch/publicationsanddata/publicationsipcc_fourth_assesment_synthesis_report.htm

IPCC, 2008.Climate Change and Water, www.ipcc.ch/pdf/technical-papers/climate-change-wateren.pdf.

IPCC, 2014. Climate Change, 2014 Synthesis Report.

Pal, J.S., Giorgi, F., Elguindi, X.Bi., Solmon, N.F., Gao, X.S., Rausche, R.A., Francisco, R., Zakey, A., Winte, R.J., Ashfaq, M., Syed, F., Bell S., Diffenbaugh, J.L.N.S., Karmacharya, J., Konare, A., Martinez, D.R.P., Sloan, L.C. and Steiner, A., 2007. Regional climate modeling for the developing world: The ICTP RegCM3 and RegCNET. Bulletion of the American Meteorological Society, 88, 1395-1409.

Panagopoulos, A., Voudouris, K., Hionidi, M. and Koumantakis, J., 2002. Irrational water resources management impacts on the coastal aquifer system of Korinthia, Proc. of International Conference, Restoration and Protection of the Environment V, July 2002, Skiathos, 1, 419-426.

Sreedevi, P.D., 2002. Climatic water balance and droughts of Pageru river basin, Cuddapah district, Andhra Pradesh, Environmental Geology, 41, 681-689.

Thornthwaite, C.W., 1948. An approach toward a rational classification of climate, Geographical Reviews, 381, 55-94.

Thornthwaite, C.W. and Mather, J.R., 1955. The water balance, Publications in Climatology, 88, 104, Laboratory of Climatology, Climatologic Dresel Institute of Technology.

Tolika, K., Zanis, P. and Anagnostopoulou, C., 2012.Regional climate scenarios for Greece: Future temperature and precipitation projections for ensembles of RCMs, Global NEST Journal, 14(4), 407-421.

Touazi, M., Ladorde, J.P. and Bhiry, N., 2004. Modelling rainfall-discharge at a mean inter-yearly scale in northern Algeria, Journal of Hydrology, 296, 179-191.

Venetsanou, P., Kazakis, N., Anagnostopoulou, C., Kolokutha, E. and Voudouris, K., 2014. Assessment of the climate changes on groundwater balance using climate and groundwater flow models. A case study of the coastal area of Peraia-Epanomi, $10^{\text {th }}$ Hydrogeological Congress of Greece, Thessaloniki, 2014, October, 2, 57-66. 
Voudouris, K. and Lambrakis, N., 1993. Statistical characteristics of the rainfall of Western Greece, Proc. $2^{\text {nd }}$ Panellenic conference on Hydrogeology, 1, 33-41 (in Greek).

Voudouris, K., Hionidi, M., Panagopoulos, A. and Koumantakis, J., 2002. Extreme climatic events in the Prefecture of Korinthos (Greece) and their impact on groundwater resources, Proc. of $5^{\text {th }}$ International Conference, Water resources management in the era of transition. European Water Resources Association, Athens, 107-114.

Voudouris, K., 2006. Groundwater balance and safe yield of the coastal aquifer system in NEastern Korinthia, Greece, Applied Geography, 26, 291-311.

Voudouris, K. and Danopoulos, C., 1993. Program for assessment of real evapotranspiration and water excess, based on Thornthwaite-Mather's method, Geotechnic Scientific Issue, 4, 78-84 (in Greek). 